\title{
VALUING USER PREFERENCES FOR IMPROVEMENTS IN PUBLIC NATURE TRAILS AROUND THE SUNDAYS RIVER Estuary, EASTERn CAPE, SOUTH Africa
}

\author{
Deborah Lee* \\ Nelson Mandela Metropolitan University \\ deborah.lee@nmmu.ac.za \\ Stephen G Hosking* \\ Mario du Preez+ \\ Cape Peninsula University of Technology \\ Nelson Mandela Metropolitan University
}

Received: April 2014

Accepted: February 2015

\begin{abstract}
Many valuations have been made of changes to in-estuary attributes, but few have been made of outof-estuary attributes. From a recreation perspective, an important type of out-of-estuary attribute is the availability of public paths by which to access attractive features of the estuary environment. This paper values an improvement in the level of public access in the form of an additional nature trail along the banks of the Sundays River Estuary in the Eastern Cape, but does not compare this value with the costs. By means of choice experiment modelling analyses it is estimated that in 2010 the marginal willingness to pay for an investment in a nature trail was R34 per user per annum. In order to determine whether the development of this trail is efficient, this benefit (R34 per user per annum) needs to be compared to the cost of the development, an analysis that remains to be done. However, this finding does serve to provide guidance on how much funding could efficiently be allocated to such a development - about ZAR1.22 million, assuming a social discount rate of $8.38 \%$.
\end{abstract}

Keywords

Estuary, willingness to pay, choice experiment, public access, recreational attributes

*Dr D Lee is a senior lecturer in the Department of Economics, Nelson Mandela Metropolitan University, South Africa.

\#Prof SG Hosking is head of the business school at the Cape Peninsula University of Technology, South Africa.

+Prof M du Preez is professor in the Department of Economics, Nelson Mandela Metropolitan University, South Africa. 


\section{INTRODUCTION}

The Sundays River Estuary is a major tourist attraction (Cowley, Childs \& Bennett, 2009). Recreational activities that occur at the Sundays River Estuary generate values for various participants, most notably tourism revenues for local businesses. The demands of a growing population, however, have led to increased pressures on the estuary as a recreational outlet and may, as a result, threaten the sustainability of the estuary's environmental service flows. As the estuary's user population increases, decision-makers and stakeholders face two important trade-offs with respect to these service flows. Firstly, they must trade off improved public access to the attractions of the estuary against preserving the naturalness and undisturbed feel of the environment. Secondly, they must trade off demand for public spending on improved public access with demand for public spending on other services, for example, housing and health (Hay, Hosking \& McKenzie, 2008). Several concerns that must be kept in mind when determining the optimal level of public path provided at the Sundays River Estuary are (1) the protection of the existing fragile natural resources, (2) private property privacy concerns, (3) the safety and security provided for public use, and (4) the need for investment in the recreational appeal of the estuary (Vickey, 2003).

The Sundays River Estuary $\left(33^{\circ} 43^{\prime} S, 25^{\circ} 25^{\prime} \varepsilon\right)$ is situated in the Eastern Cape ( $\left.\varepsilon C\right)$, approximately 40 kilometres $(\mathrm{km})$ northeast of Port Elizabeth (see FIGURE 1 ). The estuary is approximately $20 \mathrm{~km}$ long, is permanently open and discharges into Algoa Bay, in the Indian Ocean (MacKay \& Schumann, 1990).
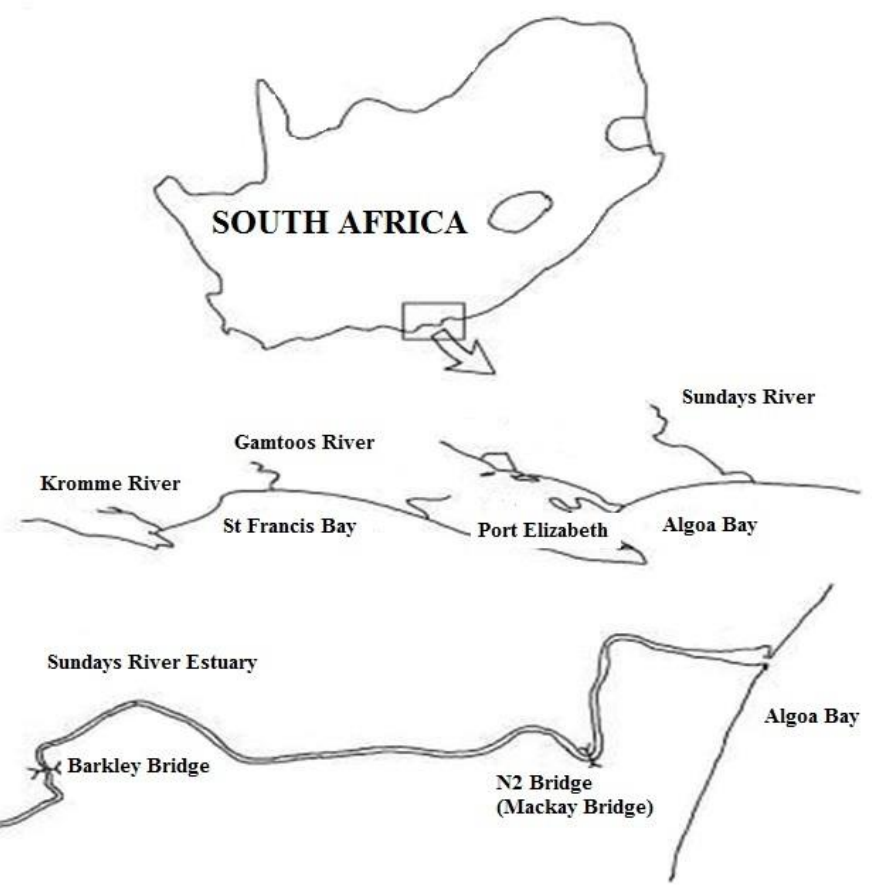

\section{FIGURE 1: The Sundays River Estuary}

Source: Baird (2002) 
Public access at the Sundays River Estuary is subject to a number of restrictions - some of which are natural barriers and some of which are man-made. The former includes steep, inaccessible banks. The latter includes private residential properties on land adjacent to the banks of the estuary and private ownership of land adjacent to the estuary's banks (Cowley et al., 2009; Unit for Integrated Environmental and Coastal Management (IECM), 2010). The Cowley et al. (2009) study divided the recreational area of the Sundays River Estuary into six zones (see FIGURE 2).

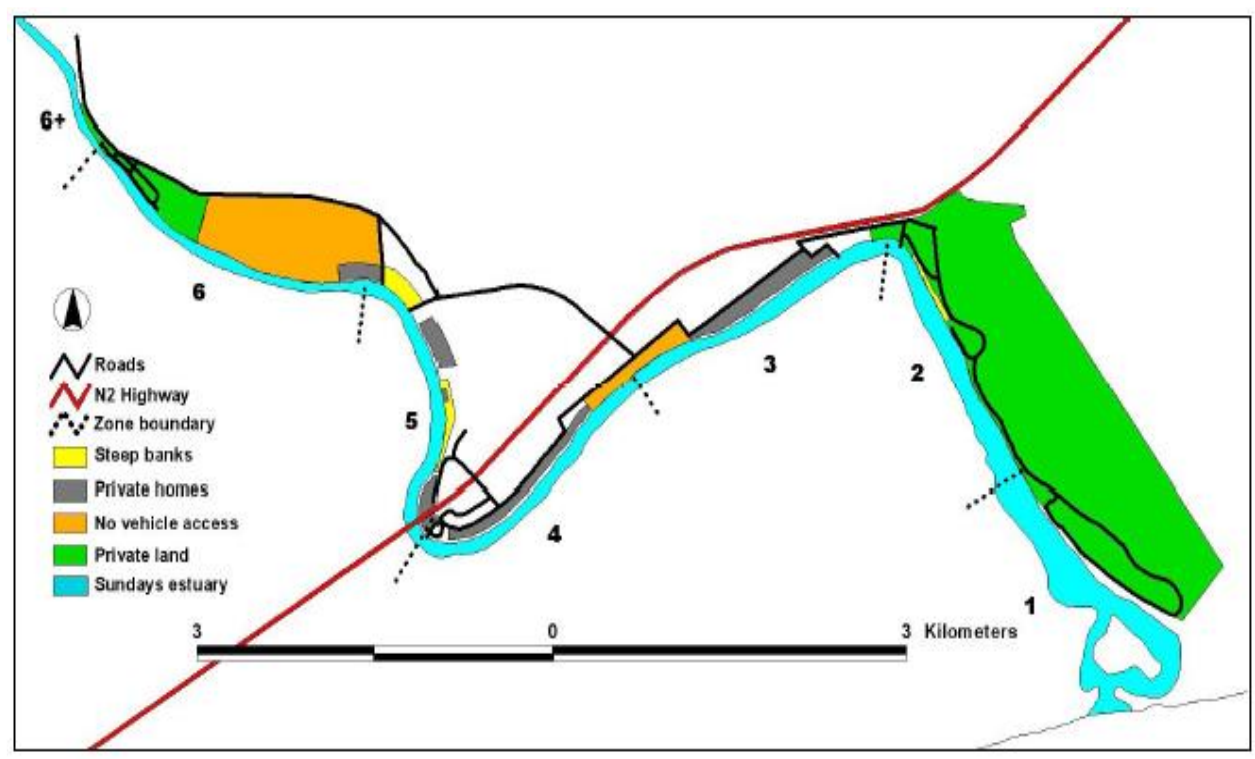

\section{FIGURE 2: Spatial zones of the Sundays River Estuary}

Source: Cowley et al. (2009)

Public access to the west bank of the estuary is limited by privately-owned farms (no public access save for farm staff), the N2 national highway (this permits access to pedestrians only), and the Mackay Rail Bridge, which is currently closed and permits only bicycle and pedestrian access (Cowley et al., 2009). Access to the east bank of the estuary, from the mouth of the estuary up to the Pearson Park caravan park, is restricted due to the presence of privately owned land. Estuary users can only access this bank if they are prepared to pay an access fee. Access to this bank is further hampered by the existence of a steep, rocky cliff situated at the northern end of the east bank. This makes shore access difficult and dangerous during low tide and impossible during high tide (Cowley et al., 2009). Vehicle access does exist on the east bank, with the exception of the area beyond the parking lot, to the south of the ablutions. The north bank of the estuary, between the N2 Bridge and the Pearson Park caravan park, is largely residential. The estuary banks and riparian zone on this bank are frequented mostly by residents, but the area is accessible to the general public via a wide open grass space between the residential dwellings and the estuary. Vehicle access to the estuary is restricted to two distinct points: one near the petrol station in the north-east corner of the estuary, and the other at the slipway located adjacent to the N2 highway. Except for these two access points, there are virtually no other vehicle access points along this stretch of the estuary (Cowley et al., 2009). The estuary bank to the north of the N2 highway is accessible by vehicle, but is restricted to the road that leads up to the Mackay Rail Bridge. The east bank to the north of the N2 Bridge is mainly occupied by residential properties. 
The estuary banks along this stretch are also steep and inaccessible (Cowley et al., 2009). The area to the north of the Mackay Rail Bridge is hardly accessible by road.

In the vicinity of Colchester and Cannonville, private jetties have proliferated in an ad-hoc manner along the northern bank of the Sundays River Estuary. Most of these jetties have been constructed on Municipal Public Open Space without authorisation. Although most of the jetties are situated on Municipal land, access is controlled by those who erected them.

In their status quo assessment report, Afri-Coast Engineers recommended that "... a continuous strip of green open space be preserved along the river banks (of the Sundays River Estuary) to form an aesthetic nature trail providing a valuable asset to the area for both local residents and tourists" (Afri-Coast Engineers, 2004). The green open space must constitute a sufficiently wide river frontage to allow for safe public access. The engineering company further recommended that "... negotiations should be initiated with the private land owners who own private land along the river edges (of the Sundays River Estuary) to investigate a mutually beneficial partnership to conserve this ecologically valuable land" (Afri-Coast Engineers, 2004). Other privately owned land could be incorporated into conservancies, or bought by the Nelson Mandela Bay Municipality, in order to conserve these areas and to incorporate them into the Nelson Mandela Metropolitan Open Space System (Afri-Coast Engineers, 2004).

The National Water Act of 1998 governs public access to estuaries in South Africa, but is vague on how this public access must be managed and conserved (NWA, 1998). It states: "A person may, subject to this Act-... (e) For recreational purposes - (i) use the water or the water surface of a water resource to which that person has lawful access; or (ii) portage any boat or canoe on any land adjacent to a watercourse ..." The introduction of a nature trail fronting the banks of the Sundays River Estuary appears to be allowed for in the Act, as it would be 'adjacent to the watercourse'. From a social perspective it would improve the quality of the public land fronting the water's edge and make it more appealing for recreational shore fishing, as well as provide further areas for other recreational activities, such as bird watching or walking. But what would society (the users) be prepared to pay for the development of such a facility? This paper uses the choice experiment (CE) methodology to estimate the recreational user's willingness to pay (WTP) for this development, and by so doing, provides guidance to the estuary management authorities on what level of resources they can efficiently allocate to the path development project.

\section{LITERATURE REVIEW}

The literature that exists on the valuation of wetlands, estuaries and rivers is largely focussed on valuing specific attributes of interest within each site. Studies that make use of the $C \varepsilon$ methodology to value these attributes include Opaluch, Grigalunas, Diamantides, Mazzotta and Johnston (1999), Heberling, Shortle and Fisher (2000), Hanley, Alvarez-Farizo, Wright and Nevin (2001), Economics for the Environment Consultancy (EFTEC) (2002), Hanley, Adamowicz and Wright (2002), Hearne and Salinas (2002), Landry, Keeler and Kriesel (2003), Eggert and Olsson (2004), Windle and Rolfe (2004), Bateman, Cole, Georgiou and Hadley (2005), Birol, Karousakis and Koundouri (2006), Huang, Poor and Zhao (2007), Kragt, Bennett, Lloyd and Dumsday (2007), Kragt and Bennett (2009), Smyth, Watzin and Manning (2009), and Beharry-Borg and Scarpa (2010). In South Africa, there have only been a few studies reported that make use of a choice modelling technique to value environmental attributes. Most notably, a joint contingent valuation-conjoint valuation approach was applied in order to value river quality improvements 
in the Kruger National Park catchment areas (Turpie \& Joubert, 2001), and a CE was applied at the Bushmans River Estuary (Oliver, 2010).

The Turpie and Joubert (2001) study applied a joint valuation approach in order to determine the effect of a change in river quality on tourism values in the Kruger National Park catchment areas. Whilst this study selected four attributes with four levels each to represent differing levels of river quality, it did not include a monetary attribute. In order to express respondent utility and preferences in monetary terms, a cost variable is required. This study, however, chose to include two contingent valuation-style questions that provided values for the 'best' and 'worst' case scenarios relative to the status quo. Although normal practice for a $C \varepsilon$ involves the inclusion of a cost variable, this study was able to derive percentage changes in tourist visitation though the application of this joint technique. Results suggested that approximately $30 \%$ of tourism business would be lost if rivers were totally degraded. In terms of assessing which attributes were considered most important by tourists, appearance of the river scape (scenery) had the greatest influence on recreational value, followed by water bird diversity (Turpie \& Joubert, 2001).

The Oliver (2010) study applied a CE to the Bushmans River Estuary, in the EC Province, and compared the results with those of an application of a contingent valuation method (CVM) study done by Van Der Westhuizen (2007). Welfare measures derived from the C $\varepsilon$ study were about $30 \%$ less than the welfare measures derived from the CVM study (Oliver, 2010). Reasons cited for this difference included different samples of users, as well as the possibility of embedding bias in the derived CVM estimates. The Oliver (2010) study suffered from several deficiencies: too many attributes were included in the experimental design, and two cost attributes (instead of one) were included in the experimental design. An auxiliary regression test revealed the presence of multicollinearity, implying that the orthogonality of the design was compromised, the sample size was small by international standards, and no attempt was made to test for possible sources of heterogeneity.

The value of improved public path access has not been addressed by many empirical studies - only a small number of international ones exist. To the authors' knowledge, this is the first attempt in South Africa to value public access, and more specifically the development of a nature trail, via non-market valuation methods (including the travel cost method (TCM) and the CVM).

In a CVM study carried out by Bennett, Tranter, Beard and Jones (1995), it was found that individual visitors were willing to pay UKfl.11 per visit for access to woodland walks in England (the walks are located in a recreation site).

Kline and Swallow (1998) estimated WTP values for public access through a causeway to Gooseberry Island, Massachusetts, United States of America (USA), by using the CVM. Results suggest that the estimated average value of coastal access to the island is US\$3.06 for weekdays and US\$4.18 for weekends and holidays. If it is assumed that a visitor's WTP for access to the island during the off-season is only half that of the summer season, then a conservative estimate of the aggregate annual value of public access is US\$412 882 (1995 dollars). The estimated cost of maintaining the causeway at the time was approximately US\$200000 per annum.

Bennett, Tranter and Blamey (2003) conducted a CVM study to estimate the value visitors attach to access on the Ridgeway National Trail in the United Kingdom. The study's results reveal that individuals are willing to pay UKE1.24 per visit to access this trail, which translates into an annual total benefit of UKf186 000 .

Betz, Bergstrom and Bowker (2003) used a contingent trip model (a hybrid model comprising elements of both the TCM and the CVM) to determine the value of a potential rail trail in Georgia, 
USA. The results of the study show that an individual's per trip consumer surplus equals between US\$18.46 and US\$29.23 and the total consumer surplus exceeds US\$7.5 million.

Bowker, Bergstrom and Gill (2007) employed the TCM to estimate individuals' consumer surplus for access to the Virginia Creeper Rail Trail in Virginia, USA. The results reveal that the individual net economic value for recreation access to the Virginia Creeper Rail Trail was, assuming no time cost, equal to US\$22.78 per person per trip and the total value equal to US\$2.3 million, whereas under the assumption of a time cost equal to one quarter of the average wage rate, the individual net economic value was estimated at US $\$ 38.90$ per person per trip and US\$3.9 million in total.

TABLE 1 below provides a summary of the results of the international studies conducted on WTP for public access.

TABLE 1: Summary of international studies' results

\begin{tabular}{cccc}
\hline Study & Methodology & Individual value & Total value \\
\hline Bennett et al. (1995) & CVM & UKfl.11 per visit & Not reported \\
Kline and Swallow (1998) & CVM & US\$3.16 per visit & US\$412882 \\
Bennett et al. (2003) & CVM & UKf1.24 per visit & UKf184000 \\
Betz et al. (2003) & Contingent trip model & US\$18.46- & US\$7.5 million \\
& & US\$29.23 per visit & \\
Bowker et al. (2007) & TCM & US\$22.78 - & US\$2.3 million - \\
& & US\$38.90 & US\$3.9 million \\
\hline
\end{tabular}

Sources: Bennett et al., 1995; Kline \& Swallow, 1998; Bennett et al., 2003; Betz et al., 2003; Bowker et al., 2007

\section{CASE STUDY METHODOLOGY}

\subsection{Choice experiment design and attribute selection}

Interviews were conducted with experts as well as members of the Sundays River Ratepayers Association. These interviews identified the most important issues facing recreational users of the Sundays River Estuary and specified them in terms of attributes with differing levels. One of the key problems identified related to the lack of adequate public access to the estuary. Based on these discussions, and following the steps outlined by Hasler, Lundhede, Martinsen, Neye and Schou (2005), a questionnaire was developed and pre-tested through a pilot survey. Following this pilot survey, some editorial changes were made to the questionnaire in order to improve its clarity and reduce the overall cognitive burden on the respondent. The $C \varepsilon$ section of the edited questionnaire included three management attributes, namely 'Physical size of fish stocks caught', 'Boat congestion' and 'More public access?' These three attributes had two qualitative levels each. The qualitative attributes were used because respondents related better to these they were less cognitively demanding (see also Hasler et al., 2005). The fourth attribute represented the payment vehicle and was defined as an annual environmental levy added on to the existing boat licence fee structure. This cost variable was expressed by four different Rand values in the $C \varepsilon$. 
TABLE 2: The $C \varepsilon$ attributes and their levels

\begin{tabular}{|c|c|c|}
\hline Indicator/attribute & Levels & Description of levels \\
\hline \multirow{2}{*}{$\begin{array}{c}\text { Physical size of fish stocks } \\
\text { caught }\end{array}$} & Mostly small fish now & $\begin{array}{l}\text { Catch and retain whatever fish } \\
\text { species you want 'today' }\end{array}$ \\
\hline & $\begin{array}{l}\text { None now but bigger and } \\
\text { more fish next year }\end{array}$ & $\begin{array}{l}\text { Keep no undersize fish now but } \\
\text { more and bigger fish next year }\end{array}$ \\
\hline \multirow{2}{*}{ Congestion } & Hear and see few boats & $\begin{array}{l}\text { The recreational user sees and } \\
\text { hears a few boats }\end{array}$ \\
\hline & Hear and see many boats & $\begin{array}{l}\text { The recreational user sees and } \\
\text { hears many boats }\end{array}$ \\
\hline \multirow{2}{*}{ More public access } & yes & $\begin{array}{c}\text { Establish a path access along } \\
\text { the banks of the estuary }\end{array}$ \\
\hline & No & $\begin{array}{l}\text { Do not establish a path access } \\
\text { along the banks of the estuary }\end{array}$ \\
\hline \multirow{4}{*}{ Cost (ZAR) } & RO & \multirow{4}{*}{$\begin{array}{l}\text { A fixed annual sum added to the } \\
\text { existing boat license fee. This } \\
\text { added sum will be directed back } \\
\text { to the Sundays River fishery as a } \\
\text { fishery quality levy }\end{array}$} \\
\hline & R45 & \\
\hline & $\mathrm{R} 90$ & \\
\hline & $\mathrm{R} 120$ & \\
\hline
\end{tabular}

Source: Authors

It was found to be the most understandable and least controversial option out of those discussed in the focus groups. Attributes selected for this study and their corresponding levels are presented in TABLE 2.

The two alternatives presented to the recreational users of the estuary were different combinations of these three management attributes and their levels with a cost value attached. For the purposes of this study, a status quo or 'opt out' alternative was not included. The reason for this was twofold. It was difficult to define a status quo option, as some of the current recreational uses pertaining to the estuary can be defined as illegal, for example, bag and size limits in the fishery are currently not being adhered to. In addition, it was thought unnecessary to include a status quo (opt out) alternative when the purpose of the study was to guide policymaking (Hasler et al., 2005).

An introductory section was provided at the beginning of the $C \varepsilon$ questions to familiarise the respondent with the different management attributes and their levels. Information on the $C \varepsilon$ payment was also presented so that the respondents were aware of the payment vehicle, as well as the need to consider the constraints on the household's budget. The assumptions with respect to the payment were (1) that the costs of implementing the policy alternatives would be covered by the recreational users of the estuary, and (2) that all users would contribute equally to the implementation of the scenarios by means of a fixed annual sum per household.

Overall, four attributes were defined. Three of these attributes had two levels each, and one had four levels. A full factorial design $(2 \times 2 \times 2 \times 4=32)$ was generated using SPSS, yielding 32 different treatment combinations or alternatives. These alternatives were randomly allocated to 32 
different questionnaires. Each questionnaire contained four choice sets, and within each choice set, the respondent had to make a choice (trade-off) between two alternatives. Two alternatives were adopted in this case, as more than two per choice set can result in 'respondent fatigue' (Bateman, Carson, Day, Hanemann, Hanley, Hett, Jones-Lee, Loomes, Mourato, Ozdemiroglu, Pearce, Sugden \& Swanson, 2002). A sample choice set is provided in TABLE 3, in which Option B was selected.

TABLE 3: Sample choice set

\begin{tabular}{ccc}
\hline Attribute & Option $A$ & Option $B$ \\
\hline Physical size of fish stocks caught & Mostly small fish now & $\begin{array}{c}\text { None now but bigger and more fish } \\
\text { next year }\end{array}$ \\
Congestion & Hear and see few boats & Hear and see few boats \\
More public access & Yes & No \\
Cost to you(ZAR) & 45 & 0 \\
\hline I would choose & & $\checkmark$ \\
\hline (IICK ONE BOX ONLY): & & \\
\hline
\end{tabular}

Source: Authors

\subsection{Sample design and data collection}

The population of interest with respect to the Sundays River Estuary was all users and potential users of the recreational services provided by the estuary. The sample frame, however, could not be compiled, as this population does not reveal itself until it visits the estuary. As it was impossible to identify a sample frame, the closest to this objective was knowledge of the sample population and use of this knowledge to sample select. This form of non-list sampling can be used when the target population refers to visitors to a beach, or in this case, an estuary (Bateman et al., 2002; Dillman, Smyth \& Christian, 2009). It entails on-site sampling, and is known as an intercept survey (Bateman et al., 2002). Two approaches to the determination of sample size in choice modelling exercises are often proposed (Hensher, Rose \& Greene, 2005): the use of probability sampling and rule of thumb. Probability sampling is very often abandoned due to practical considerations (budget and time constraints). A 'rule of thumb' approach was used to calculate the minimum sample size required to estimate a model of choice using unlabelled experiments and design attributes only - a sample of 50 respondents each exposed to 16 choice sets is thought to be capable of yielding meaningful and significant results (Bennett \& Adamowicz, 2001). This translates into a sample of 200 respondents if they are offered 4 choice sets each.

The face-to-face interview method is the most common approach to use when valuing recreational sites (Lee \& Han, 2002). This personal interview method was adopted for this study. Although costly, it affords the interviewer the best opportunity to encourage the respondents to cooperate with the survey. The interviewer is also given an opportunity to explain complex information and valuation scenarios to the respondent - which is very important in the $C \varepsilon$ setting (Mitchell \& Carson, 1989). The Sundays River Estuary questionnaire was administered on-site by four trained interviewers during August, 2010 - in order to capture as many recreational visitors as possible, these interviews were conducted over the weekends. Interviewers approached every $n^{\text {th }}$ potential respondent and asked them if they would be willing to spend approximately 15 minutes filling in the questionnaire. In total, 175 completed questionnaires were collected, a 
number below the recommended sample size. Although a larger sample size would definitely improve future research, a sample size of 175 is still considered adequate in order to estimate 'robust' multinomial models, since even this relatively moderate sample produces a large number of observations - each respondent makes four choices, thus delivering 700 observations ( $175 * 4$ ) (Hensher et al., 2005; Snowball, Willis \& Jeurissen, 2008).

\subsection{Statistical methods}

The theoretical basis of C $\varepsilon$ is couched in random utility theory (RUT). It is based on the assumption that individuals make their choices based on the good's observable attributes, together with a random element:

$$
U_{i q}=V_{i q}\left(\beta x_{i q}\right)+\varepsilon_{i q}
$$

where $x_{i q}$ is a vector of observed attributes, and $\beta$ is a vector of the parameters to be estimated (Hanley et al., 2001). This indirect utility function comprises one observable component of utility, $V_{i q}$, and a random component, $\varepsilon_{i q}$. As mentioned above, the $C \varepsilon$ was designed so that each respondent (visitor to the Sundays River Estuary) would be offered four choice sets, each consisting of two estuary management alternatives where each alternative is defined by specific attributes and their respective levels. Analysing choices between two alternatives as a function of the attributes of the alternatives requires the use of a conditional logit $(\mathrm{CL})$ model. The $\mathrm{CL}$ model has the following form:

$$
P\left(U_{i q}>U_{i j}, \forall j \neq q\right)=\frac{\exp \left(\mu V_{i q}\right)}{\sum_{j \in C}^{a} \exp \left(\mu V_{i j}\right)}
$$

where there are $a$ different alternatives in choice set $C$. The scale parameter, $\mu$, is typically assumed to be one (Ben-Akiva \& Lerman, 1985). This model, however, assumes that random components do not exhibit serial correlation, i.e. they are independent of irrelevant alternatives (IIA) (Bhat, Eluru \& Copperman, 2000). Also, it does not allow variations to an attribute across individuals (Bhat et al., 2000). Unobserved respondent characteristics can, however, affect responses to the choice questions. If these unobserved characteristics are ignored, biased and inconsistent choice probability estimates could result (Bhat et al., 2000). These weaknesses are addressed in the random parameter logit (RPL) model (Carlsson, Frykblom \& Liljenstolpe, 2003; Morey \& Rossman, 2003; Birol et al., 2006). The RPL model generalises the CL model by allowing the coefficients of observed variables to vary randomly over individuals rather than being fixed (Louviere, Hensher \& Swait, 2000; Hynes \& Hanley, 2005):

$$
P\left(j \mid \mu_{j}\right)=\frac{\exp \left(\alpha_{j i}+\theta_{j} \mathbf{z}_{i}+\delta_{j} \mathbf{f}_{j i}+\beta_{j i} \mathbf{x}_{j i}\right)}{\sum_{j=1}^{J} \exp \left(\alpha_{j i}+\theta_{j} \mathbf{z}_{i}+\delta_{j} \mathbf{f}_{j i}+\beta_{j i} \mathbf{x}_{j i}\right)}
$$

where $\alpha_{j i}$ is a fixed or random alternative specific constant (ASC) with $j=1, \ldots$, Jalternatives and $i$ $=1, \ldots$, / individuals; and $\alpha_{j}=0, \theta_{j}$ is a vector of individual-specific parameters, $\delta_{j}$ is a vector of non-random parameters, $\beta_{j i}$ is a parameter vector that is randomly distributed across individuals - with $\mu_{i}$ a component of this $\beta_{j i}$ vector, $\mathbf{z}_{i}$ is a vector of individual-specific characteristics, for example, income, $\mathbf{f}_{j i}$ is a vector of individual-specific and alternative-specific non-randomised attributes, and $\mathbf{x}_{j i}$ is a vector of individual-specific and alternative-specific randomised attributes. The component $\mu_{i}$ represents the individual-specific random disturbance of unobserved heterogeneity (Train, 1998). 
In order to estimate this model, it is often assumed that the parameters $\beta$ are either normally, triangularly, uniformly or log-normally distributed over the population of individuals (Bhat et al., 2000; Bhat, 2001). Normally distributed parameters, means and standard deviations of coefficients can determine to what extent respondents place positive or negative values on a change in an environmental attribute (Train, 2003).

\section{RESULTS}

\subsection{Socio-economic characteristics}

This section describes the data collected from the responses from the socio-economic section of the questionnaires. The only other socio-economic information available was that gathered in the Forbes (1998), and more recently, the Cowley et al. (2009) studies. The Forbes (1998) study captured data on the recreational users of the estuary, while the Cowley et al. (2009) study captured data on both recreational and subsistence users of the estuary. Comparisons with the Cowley et al. (2009) study are possible for the following socio-economic characteristics: residential location, age, gender and education. The Forbes (1998) study allows comparisons for residential location only (see TABLE 4). Selected socio-economic results are summarised as follows:

- The majority (91\%) of visitors came from areas less than $50 \mathrm{~km}$ away from the estuary.

- The majority ( $66 \%)$ of recreational users surveyed were over the age of 31 .

- The majority (84\%) of recreational users surveyed are male.

- The average gross annual income for the sample was R184 000.

- Of the respondents sampled, $35 \%$ had a matric qualification with university exemption.

TABLE 4: Socio-economic characteristics

\begin{tabular}{|c|c|c|c|}
\hline \multirow[b]{2}{*}{ Characteristic } & \multicolumn{3}{|c|}{$\%$ of Respondents } \\
\hline & This Study & $\begin{array}{l}\text { Forbes (1998) } \\
\text { Study }\end{array}$ & $\begin{array}{l}\text { Cowley et al. } \\
\text { (2009) Study }\end{array}$ \\
\hline Distance $<50 \mathrm{~km}$ from Estuary & 91 & 84.9 & 91.2 \\
\hline Age $<31$ years & 66 & - & 65 \\
\hline Gender: Male & 84 & - & 92 \\
\hline Gender: Female & 16 & - & 8 \\
\hline Average Income (ZAR) & 184000 & - & - \\
\hline $\begin{array}{l}\text { Education: Matric with } \\
\text { Exemption }\end{array}$ & 35 & - & 28 \\
\hline
\end{tabular}

Sources: Authors; Forbes et al. (1998); Cowley et al. (2009)

\section{$4.2 C \varepsilon$ results}

TABLE 5 reports the estimation results of the two model specifications. 
TABLE 5: Estimation results of the C $\varepsilon$

\begin{tabular}{|c|c|c|c|c|}
\hline \multirow[t]{2}{*}{ Variables } & \multicolumn{2}{|c|}{$C L$} & \multicolumn{2}{|c|}{$R P L$} \\
\hline & Coeff. & Std err. & Coeff. & Std err. \\
\hline Physical Size of Fish & $1.59 \star \star$ & .14 & $1.95 \star \star$ & .53 \\
\hline Congestion & $-.34 \star \star$ & .13 & $-.39 \star$ & .15 \\
\hline Public Access & $.34 \star \star$ & .12 & $.38 * \star$ & .14 \\
\hline Cost $^{1}$ & $-.01 \star \star$ & .00 & $-.01 \star \star$ & .00 \\
\hline \multicolumn{5}{|c|}{ Standard deviations of random parameters } \\
\hline Physical Size of Fish & & & 1.18 & .97 \\
\hline Congestion & & & .28 & .69 \\
\hline Public Access & & & .18 & 1.08 \\
\hline No. of Respondents & \multicolumn{2}{|c|}{175} & \multicolumn{2}{|c|}{175} \\
\hline No. of Observations & \multicolumn{2}{|c|}{700} & \multicolumn{2}{|c|}{700} \\
\hline Pseudo $\mathrm{R}^{2}$ & \multicolumn{2}{|c|}{.22} & \multicolumn{2}{|c|}{.24} \\
\hline
\end{tabular}

Source: Results from statistical analysis

*indicates that parameter is statistically significant at the $5 \%$ level. ** indicates significance at the $1 \%$ level

1. Cost was specified as a non-random parameter in the RPL.

The coefficients in both models have the correct signs, a priori, and are significantly different from zero at the $95 \%$ confidence level (at the least). The cost attribute parameter is as expected i.e. significant and has a negative sign in both models estimated. The probability that a specific alternative in the choice set would be chosen was reduced: the lower the physical size of the fish stock, the higher the amount of boat congestion, the lower the amount of public access available, and the higher the environmental quality levy.

In the case of the $\mathrm{CL}$ model, the significant coefficients can be interpreted by estimating their odds ratios. This is done by calculating the antilog - the value of 10 to the power of the coefficient's value - of the various coefficients. Odds interpretation indicates how an increase (decrease) in an attribute's level would result in a change in the probability of choosing an alternative (either option A or B in this study) from the choice set, which includes this increase (decrease). With respect to the attribute of interest, i.e. public access, an increase in public access will result in an increase in the probability of a respondent choosing an alternative from the choice set, which includes this attribute level, by $2 \%$. The explanatory power of multinomialtype models is measured by the Pseudo $R^{2}$. At $22 \%$ this is a good fit for C $\varepsilon$-type studies - Louviere et al. (2000) suggested that anything between 0.2 and 0.4 can be considered very good.

With respect to the RPL model, all parameters except the cost parameter were treated as random and assumed to be normally distributed (Hasler et al., 2005). Cost was specified as fixed, and not randomly distributed, because in this case the distribution of the marginal WTP for an attribute is simply the distribution of that attribute's coefficient. The RPL model compared to the CL model has a higher level of parametric fit, as the Pseudo $R^{2}$ increases from 0.22 to 0.24 . In addition, the results reveal that the estimated RPL model shows statistically insignificant standard deviations, 
which indicates statistically similar preferences for attributes across respondents, implying a largely homogeneous recreational user group.

\subsection{Estimation of WTP values}

Measures of welfare can be calculated from the estimated coefficients in the form of marginal WTP values (Goibov, Schmitz, Bauer \& Ahmed, 2012). More generally, the marginal rates of substitution between the different attributes can be calculated from the ratios of the coefficients. The marginal WTP value for public access calculated was for a change from limited recreational appeal to an improvement in the recreational appeal of the estuary through the introduction of a path access along the estuary banks. TABLE 6 reports the implicit prices, or marginal WTP, for each of the Sundays River Estuary's recreational attributes estimated using the Delta method (Wald procedure) in LIMDEP NLOGIT Version 4.0 (Greene, 2007). This procedure automates the process of estimating standard errors for non-linear functions, such as marginal rates of substitution (Suh, 2001). As parameter coefficients are stochastic in nature, confidence intervals are also estimated. These prices are based on the RPL model coefficients instead of the $\mathrm{CL}$ model coefficients, since the former address the weaknesses of the latter, inter alia, the assumptions of the IIA and homogeneity in preferences across respondents. In addition, it has been shown that the RPL model is superior to the CL model in terms of fit (which is also the case in this study) and overall welfare estimation (Carlsson et al., 2003; Morey \& Rossman, 2003; Birol et al., 2006).

\section{TABLE 6: Marginal WTP (MWTP) for attributes (ZAR)}

\begin{tabular}{cc}
\hline Attribute & Marginal WTP value \\
\hline Physical Size of Fish Stock & $174(95 ; 253)$ \\
Congestion & $-35(-62 ;-8)$ \\
Public Access & $34(8 ; 59)$ \\
\hline
\end{tabular}

Source: Authors

*95\% confidence intervals in parentheses.

The WTP for more public access in the form of a nature trail along the banks of the Sundays River Estuary was R34.00 per user per annum. Total WTP for the nature trail development can be calculated by multiplying the number of registered boat owners, by the WTP per user per annum. Given that in 2010 there were 900 boat users registered at the private Pearson Park slipway and about 2100 non-registered users ( 3000 in total), the total WTP amounts to ZAR102 000 per annum. The latter amount should, ideally, be compared to the cost of constructing and maintaining the public nature trail in a cost-benefit analysis framework. Unfortunately, no cost information was available.

Assuming a social discount rate of $8.38 \%$ (the average 10 -years-and-over bond yield in 2010), the present value (PV) of this project can be estimated as the annual total WTP divided by the social discount rate, and amounts to ZAR1.2 million. Thus, in the absence of actual cost information it can be stated that it would be efficient to spend about ZAR1.2 million on this development in 2010 (SARB, 2013). 


\section{CONCLUSION}

This paper adds to the limited literature on the assessment of economic values of estuaries using $C \varepsilon s$, and is one of a few that has been undertaken in South Africa. Its specific aim was to determine, via discrete choice analysis, the value recreational visitors (mainly boat users) to the Sundays River Estuary attach to the development of a nature trail in order to enhance public access to the estuary. This information is necessary to design socially efficient estuary management strategies by comparing the benefits estuarine attributes, such as the nature trail, generate to the cost of project implementation. The results indicate that there is a positive and significant economic benefit associated with the public access attribute. More specifically, the study found the marginal WTP for public access to the Sundays River Estuary (through the establishment of a public nature trail) to be ZAR34 (95\% CI: ZAR8; ZAR59) per user per annum. Assuming the average user visits the estuary eleven times per year, the WTP per visit equals ZAR3.10. The value of public access (ZAR3.10 per visit) estimated for the Sundays River Estuary is substantially lower compared to the low end of values reported in the literature review above. For example, the Bowker et al. (2007) study estimated the value of public access to the Virginia Creeper Rail Trail to be US\$24.17 (2010 price levels), which is ZAR178 per visit higher than the value estimated for public access to the Sundays River Estuary (estimated at an exchange rate of ZAR7.50/US\$). A possible reason for the low WTP value estimated at the estuary relates to the income level of the average user - only ZAR184000 per annum. The median income level is even lower - approximately ZAR140 000 per annum.

The total WTP derived from the public access attribute was aggregated over the sum of the 900 registered boat users and the 2100 non-registered users (i.e. 3000 users) and amounted to ZAR102 000 per annum. Although the main group of current users are willing to pay ZAR102 000 per annum to implement such a nature trail project, it cannot be determined whether this investment is efficient, as project cost information was not collected. However, this finding does serve to provide guidance on how much funding could be allocated to such a development - this was estimated to be ZAR1.2 million (at a discount rate of $8.38 \%$ ).

With the use of the benefit transfer method, this study can provide policy-makers and other stakeholders with useful information for the management of public access issues at similar estuaries. It is, however, recommended that a cost-benefit analysis be conducted on the feasibility of this project at a later date.

\section{Acknowledgements}

We gratefully acknowledge the Water Research Commission's financial support. We would also like to thank the members of the reference group for valuable comments, insights and suggestions. This study formed part of a bigger research initiative under the auspices of the Water Research Commission (WRC) of South Africa. The research initiative is entitled "The application of choice modelling (CM) techniques to guide the management of estuaries in South Africa - case studies of the Kromme, Nahoon, Sundays and Gonubie Estuaries" (WRC Project No. KSA5/1924).

We would also like to thank an anonymous reviewer from Economic Research South Africa (ERSA) for valuable feedback, which resulted in a financial contribution from the publication of an ERSA working paper. 


\section{LIST OF REFERENCES}

Afri-Coast Engineers. (2004). Colchester Status Quo Assessment Report. Port Elizabeth: Nelson Mandela Metropolitan Municipality, Report No. P1577/01.

Baird, D. (2002). Estuaries of South Africa. Port Elizabeth: University of Port Elizabeth.

Bateman, I.J., Carson, R.T., Day, B., Hanemann, M., Hanley, N., Hett, T., Jones-Lee, M., Loomes, G., Mourato, S., Özdemiroglu, E., Pearce, D.W., Sugden, R. \& Swanson, J. (2002). Economic Valuation with Stated Preference Techniques. A Manual. Cheltenham: Edward Elgar Publishing.

Bateman, I.J., Cole, M.A., Georgiou, S. \& Hadley, D.J. (2005). Comparing contingent valuation and contingent ranking: A case study considering the benefits of urban river water quality improvements. Journal of Environmental Management, 79(2006), pp. 221-231.

Beharry-Borg, N. \& Scarpa, R. (2010). Valuing quality changes in Caribbean coastal waters for heterogeneous beach visitors. Ecological Economics, 69(5), pp. 1124-1139.

Ben-Akiva, M. \& Lerman, S. (1985). Discrete Choice Analysis: Theory and Application to Travel Demand. Cambridge: MIT Press.

Bennett, J. \& Adamowicz, W. (2001). Some fundamentals of environmental choice modelling. In J. Bennett \& R.K. Blamey (eds.) The Choice Modelling Approach to Environmental Valuation. Cheltenham: Edward Elgar Publishing (pp. 37-69).

Bennett, R.M., Tranter, R.B., Beard, N.F. \& Jones, P.J. (1995). The value of footpath provision in the countryside: a case study of public access to urban-fringe woodland. Journal of Environmental Planning and Management, 38 (3), pp. 409-417.

Bennett, R.M., Tranter, R.B. \& Blamey, R.J.P. (2003). The value of countryside access: a contingent valuation survey of visitors to the Ridgeway National Trail in the United Kingdom. Journa/ of Environmental Planning and Management, 46(5), pp. 659-671.

Betz, C.J., Bergstrom, J.C. \& Bowker, J.M. (2003). A contingent trip model for estimating rail-trail demand. Journal of Environmental Planning and Management, 46(1), pp. 79-96.

Bhat, C.R., Eluru, N. \& Copperman, R.B. (2000). Flexible model structures for discrete choice analysis. In D.A. Hensher \& K.J. Button (eds.) Handbook of Transport Modelling, Vol. 1: Handbooks in Transport. Oxford: Pergamon Press (pp. 71-90).

Bhat, C. R. (2001). Quasi-random maximum simulated likelihood estimation of the mixed multinomial logit model. Transportation Research B, 35(7), pp. 677-695.

Birol, E., Karousakis, K. \& Koundouri, P. (2006). Using a choice experiment to account for preference heterogeneity in wetland attributes: the case of Cheimaditida wetland in Greece. Ecological Economics, 60(1), pp. 145-156.

Bowker, J.M., Bergstrom, J.C. \& Gill, J. (2007). Estimating the economic value and impacts of recreational trails: a case study of the Virginal Creeper Rail Trail. Tourism Economics, 13(2), pp. 241260.

Carlsson, F., Frykblom, P. \& Liljenstolpe, C-J. (2003). Valuing wetland attributes: an application of choice experiments. Ecological Economics, 47(1), pp. 95-103.

Cowley, P.D., Childs, A-R. \& Bennett, R.H. (2009). A Survey of Fishery Resource Utilisation and Recreational Activities on the Sundays Estuary with Implications for Management. Grahamstown: South African Institute for Aquatic Biodiversity, World Wildlife Fund - South Africa Report. 
Dillman, D.A., Smyth, J.D. \& Christian, L-M. (2009). Internet, Mail and Mixed-Mode Surveys: The Tailored Design Method. New Jersey: Wiley and Sons.

Economics for the Environment Consultancy Ltd (EFTEC). (2002). Valuation of Benefits to England and Wales of a Revised Bathing Water Puality Directive and Other Beach Characteristics Using the Choice Experiment Methodology. London: EFTEC, Report to the Department for Environment, Food and Rural Affairs.

Eggert, H. \& Olsson, B. (2004). Heterogeneous Preferences for Marine Amenities: A Choice Experiment Applied to Water Quality. Goteborg: Goteborg University. (Department of Economics Working Papers in Economics series no. 126).

Forbes, V.R. (1998). Recreational and Resource Utilisation of Eastern Cape Estuaries and Development towards a Management Strategy. (Unpublished MSc dissertation). Port Elizabeth: University of Port Elizabeth.

Goibov, M., Schmitz, P.M., Bauer, S. \& Ahmed, M.N. (2012). Application of a choice experiment to estimate farmer's preferences for different land use options in Northern Tajikistan. Journal of Sustainable Development, 5(5), pp. 1-16.

Greene, W.H. (2007). NLOGIT: Version 4.0, User manual. New York: Econometric Software, Inc.

Hanley, N., Koop, G., Alvarez-Farizo, B., Wright, R. \& Nevin, C. (2001). Go climb a mountain: an application of recreation demand modelling to rock climbing in Scotland. Journal of Agricultural Economics, 52, pp. 36-52.

Hanley, N., Adamowicz, W. \& Wright, R. (2002). Do Choice Experiments Pass the Scope Test? A Test of Scope Experiment Examining the Benefits of Water Quality Improvements. Paper presented at the EAERE/AERE World Congress: Monterey, California.

Hasler, B., Lundhede, T., Martinsen, L., Neye, S. \& Schou, S.J. (2005). Valuation of Groundwater Protection versus Water Treatment in Denmark by Choice Experiments and Contingent Valuation. Denmark: National Environmental Research Institute. NERI Technical Report No. 543. Available: http://technical-reports.dmu.dk. (Accessed 15 February 2010).

Hay, D., Hosking, S.G., \& McKenzie, M. (2008). Estuaries, Economics and Freshwater: An Introduction. Pretoria: Water Research Commission.

Hearne, R. \& Salinas, Z. (2002). The use of choice experiments in the analysis of tourist preferences for ecotourism development in Costa Rica. Journal of Environmental Management, 65(2), pp. 153163.

Heberling, M., Shortle, J. \& Fisher, A. (2000). The Effect of the Number of Choice Sets on Responses in a Stated Choice Survey. Paper presented at the American Agricultural Economics Association Annual Meeting: Miami, Florida.

Hensher, D., Rose, J.M. \& Greene, W.H. (2005). Applied Choice Analysis: A Primer. Cambridge: Cambridge University Press.

Huang, J., Poor, P.J. \& Zhao, M.Q. (2007). Economic valuation of beach erosion control. Marine Resource Economics, 22(3), pp. 221-238.

Hynes, S. \& Hanley, N. (2005). Analysing Preference Heterogeneity using Random Parameter Logit and Latent Class Modelling Techniques. Ireland: The National University of Ireland, Galway.

(Environmental and Natural Resource Economics Research Unit, Working paper series no. 91).

Kline, J.D. \& Swallow, S.K. (1998). The demand for local access to coastal recreation in Southern New England. Coastal Management, 26(3), pp. 177-190. 
Kragt, M.E., Bennett, J., Lloyd, C. \& Dumsday, R. (2007). Comparing Choice Models of River Health Improvement for the Goulburn River. Paper presented at the $51^{\text {th }}$ Conference of the Australian Agricultural and Resource Economics Society: Queenstown, Australia.

Kragt, M.E. \& Bennett, J.W. (2009). Using Choice Experiments to Value River and Estuary Health in Tasmania with Individual Preference Heterogeneity. Canberra: Australian National University. Environmental Economics Research Hub Research, Report No. 0916.

Landry, C.E., Keeler, A.G. \& Kriesel, W. (2003). An economic evaluation of beach erosion management alternatives. Marine Resource Economics, 18, pp. 105-127.

Lee, C.K. \& Han, S.Y. (2002). Estimating the use and preservation values of national parks' tourism resources using a contingent valuation method. Tourism Management, 23(5), pp. 531-540.

Louviere, J.J., Hensher, D.A. \& Swait, J.D. (2000). Stated Choice Methods: Analysis and Application. Cambridge: Cambridge University Press.

Mackay, H.M. \& Schumann, E.H. (1990). Mixing and circulation in the Sundays River Estuary, South Africa. Estuarine Coastal Shelf Sciences, 31(2), pp. 203-216.

Mitchell, R.C. \& Carson, R.T. (1989). Using Surveys to Value Public Goods: The Contingent Valuation Method. Washington D.C.: Resources for the Future.

Morey, E.R. \& Rossman, K.G. (2003). Using stated-preference questions to investigate variations in willingness to pay for preserving marble monuments: classic heterogeneity, random parameters, and mixture models. Journal of Cultural Economics, 27(4), pp. 215-229.

National Water Act (NWA). (1998). Act Number 36 of 1998. Pretoria: Department of Water Affairs and Forestry - Government printers.

Oliver, C. (2010). Comparing a contingent valuation of the river inflows into the Bushmans estuary with a choice experiment valuation. (Unpublished MSc dissertation). Port Elizabeth: Nelson Mandela Metropolitan University.

Opaluch, J., Grigalunas, T., Diamantides, J., Mazzotta, M. \& Johnston, R. (1999). Recreationa/ and Resource Non-market Values for the Peconic Estuary System. Peacedale, RI: Economic Analysis Inc.

Smyth, R.L., Watzin, M.C. \& Manning, R.E. (2009). Investigating stakeholder preferences for managing Lake Champlain using a choice experiment. Journal of Environmental Management, 90(1), pp. 615623.

Snowball, J., Willis, K.G. \& Jeurissen, C. (2008). Willingness to pay for water service improvements in middle-income urban households in South Africa: a stated choice analysis. South African Journal of Economics, 76(4), pp. 705-720.

South African Reserve Bank (SARB). (2013). Quarterly Bulletin, No. 267. Pretoria: South African Reserve Bank.

Suh, J. (2001). An economic evaluation of environmental recovery of the skier-dominated area in the Mount Togyu National Park in South Korea. (Unpublished PhD thesis.) Queensland: The University of Queensland.

Train, K.E. (1998). Recreation demand models with taste differences over people. Land Economics, 74, pp. 230-239.

Train, K.ع. (2003). Discrete Choice Methods with Simulation. Cambridge: Cambridge University Press. 
Turpie, J.K. \& Joubert, A. (2001). Estimating potential impacts of a change in river quality on the tourism value of Kruger National Park: An application of travel cost, contingent and conjoint valuation methods. Water South Africa, 27(3), pp. 387-398.

Unit for Integrated Environmental and Coastal Management (IECM). (2010). Regional Estuarine Management Programme: Sundays River Management Plan. Port Elizabeth: Nelson Mandela Metropolitan University.

Van Der Westhuizen, H. (2007). Valuing preferences for freshwater inflows into the Bira, Bushmans, Kasouga, Keiskamma, Kleinemond East, Nahoon and Tyolomqa estuaries. (Unpublished MCom dissertation). Port Elizabeth: Nelson Mandela Metropolitan University.

Vickey, N. (2003). Understanding and Providing Public Access to Connecticut's Coast. Report prepared by School of Forestry and Environmental Studies, Yale University.

Windle, J. \& Rolfe, J. (2004). Assessing Values for Estuary Protection with Choice Modelling using different Payment Mechanisms. Paper presented at the $48^{\text {th }}$ Annual Conference of the Australian Agricultural and Resource Economics Society: Melbourne, Australia. 